\title{
Література:
}

1. Аристотель. Поетика, пер. Б. Тен. Харків: Фоліо, 2018. 160 с.

2. Ліхтенстейн Ж., Декюльто Е. Свропейський словник філософій: Лексикон неперекладностей. Том перший. Київ: Дух і Літера, 2009. 576 с.

3. Шмид В. Нарратология. Москва: Языки славянской культуры, 2003. 312 c.

DOI https://doi.org/10.30525/978-9934-26-004-9-76

\section{ВІЗУАЛЬНА РЕКЛАМА ОКРЕМИХ УКРАЇНСЬКИХ ПОЛІТИЧНИХ ПРОСКТІВ: ОБРАЗНО-СЕМАНТИЧНА СКЛАДОВА}

\author{
Крайлюк Л. В. \\ кандидат мистеитвознавства, \\ доцент кафедри образотворчого \\ і декоративно-прикладного мистеитва \\ Рівненського державного гуманітарного університету \\ м. Рівне, Украӥна
}

Виборчі перегони в Україні 2020 р. спричинили в реальному та віртуальному просторі масив графічної продукції, що на візуальному рівні проявляє діапазон світоглядних цінностей, які побутують в українському суспільстві або певним чином йому ж і нав'язуються. Завданням нашого дослідження $\epsilon$ аналіз візуальної семантики як прояву у політичній рекламі ключових концептів окремих політичних сил, що претендували на електоральне проходження до органів місцевого самоврядування.

Особливий інтерес для нашого дослідження викликають графічні рекламні плакати новостворених партій, що представлені лише на регіональному рівні, таких, наприклад, як «Громадський контроль». Організація досить несподівано виникла на політичній карті Рівного напередодні виборів 2020 р. Логотип політичної команди складається 3 двох частин: шрифтової та фігуративної. Шрифтова частина акцентує власне назву партії, яка виконана підкреслено брутальним рубленим шрифтом, образне наповнення якого апелює до подій сторічної давності та асоціюється 3 політичними та рекламними плакатами авторства О. Родченка [2, с. 27], В. Срмилова [1, с. 101], А. Страхова [1, с. 121]. 
Дрібнішим шрифтом зазначено, що «Громадський контроль» $є$ «першою рівненською партією». Фігуративна складова логотипу образно тяжіє до радянського плакату 60-70-х pp. [5; 6] та, особливо, твору прикладної графіки Й. Сєрєбряного «Будь бдительным!» (1941р.) [3]: стилізована правиця, міцно стиснута в кулак, з грюкотом опускається на віртуальний «стіл», видаючи таким чином «звук» у вигляді зигзагоподібних ліній, що радіально розходяться уявною поверхнею. Лінійне зображення кулака, поза всяким сумнівом, - алегоричне втілення люті потенційного виборця. Очевидно, що візуальне семантичне наповнення логотипу експлуатує ностальгічні настрої тієї частини електорату, яка ментально залишилася в ідеологічній парадигмі радянської імперії. Новостворена партія намагається образно асоціювати себе з могутністю радянської каральної системи, яка може знищити всіх корупціонерів, забрати награбоване i роздати бідним, культивуючи таким чином ультраліві політичні уподобання. Важливо зазначити, що політична сила не пройшла п'ятивідсотковий виборчий ценз i не потрапила до лав місцевого самоврядування. Це дає оптимістичний прогноз на майбутнє i підтверджує результати поведеного нещодавно соціологічного дослідження, які відображають поступові ціннісні світоглядні зміни українського суспільства у бік посилення відповідальності за якісний рівень власного життя та ситуацію в країні [7].

Ще один приклад лівацької ідеології з українським етнографічним забарвленням пропонує логотип Радикальної партії Ляшка. Тут майстерно опрацьована політтехнологами «народна лють» втілилася в графічному образі вил, який доволі цілісно в естетичному аспекті став композиційним акцентом, виконуючи водночас дві ролі - літери «ш» у написанні прізвища голови партії та, власне, яскравого візуального символу, який, крім логотипу, неодноразово фігурував у рекламних відеороликах радикалів. Архетипні закорінення візуального контенту логотипу підсилюються загальною симетричністю композиції, орнаментальним зображенням української вишивки та червоно-чорним колірним вирішенням. Зазначимо, що вдало знайдений рекламний образ Радикальної партії також не надто допоміг у здобутті голосів виборців.

Інше семантичне наповнення пропонує логотип політичної сили «Успішна країна». Стилізоване зображення голуба в польоті декодує основний світоглядний посил: «Мир будь-якою ціною». Зрозуміло, що в Україні, яка перебуває в стані гібридної війни з Росією, існує підвищений запит на припинення кровопролиття, але, на щастя, більшість не погоджується на поступову капітуляцію і втрату державності, зважаючи на низький електоральний рейтинг партії. Ще один семантичний шар 
натякає на пріоритет християнської риторики у задекларованих програмою партії ціннісних орієнтирах [4] - зображення голуба в православній i, особливо, католицькій іконографії символізує категорію Святого Духа. Шрифтова складова стилістично осучаснює логотип, водночас через нахил вертикальних елементів літер надаючи зображенню висхідної динаміки. Заокруглення графем ритмічно комбінується із заокругленими пір'їнами зображеного птаха, підкреслюючи пацифістський посил логотипа.

Зовсім інший концепт пропонує емблема партійного блоку Кернеса «Успішний Харків», образна мова якої виявляє художньо-образні конотації з коміксами та плакатами, що рекламують розважальний контент. Поясний портрет-шарж самого Геннадія Кернеса, що входить до композиційної структури логотипа, асоціюється 3 численними героями мультфільмів та дитячих книжок. Метелик, як акцентований елемент костюма протагонатора, поєднує у пропонованому віртуальному образі голови місцевої партії натяки на такі протилежні за змістом персонажі як «конферансьє», «мільярдер» чи навіть «мафіозі». В будь-якому випадку навіть сатирична пафосність головного героя логотипа контрастує 3 навмисне примітивним шрифтом синього кольору, що асоціативно відсилає до радянської мультиплікації 60 - 70-х рр. Літера «Х», виконана контурним шрифтом, акцентована різнобарвним тлом, що складається 3 квадратиків спектральних кольорів - червоного, зеленого, жовтого та синього. Така хроматична щедрість, що рідко зустрічається у зазвичай колірно-лаконічних логотипах, намагається підкреслити в цілому невиразну і позбавлену цілісності семантику безтурботності, дитячих чи «дорослих» розваг. Невідомо, чи стали вирішальними у перемозі на виборах блоку Г. Кернеса художньо-образні конотації з інфантильністю виборця, але можна $з$ упевненістю констатувати, що подібні підходи досить часто використовуються, i не лише у графічній рекламі політичних сил.

Як бачимо, образні асоціації візуальної мови політичної реклами в Україні доволі різноманітні. Через аналіз кількох окремих партійних логотипів можна 3 упевненістю стверджувати, що семантичний потенціал образного наповнення логотипів в українських політичних реаліях часто спекулює на інфантильності виборців та (або) пострадянській ностальгії, зумовлених постколоніальною свідомістю та так званим «синдромом вивченої безпомічності». Позитивним аспектом $€$ те, що розглянуті семантико-політтехнологічні прийоми не завжди знаходять відгук у електоральних симпатіях, особливо серед молодого покоління. 


\title{
Література:
}

1. Лагутенко O. GRAPHEIN ГРАФІКИ. Нариси з історії української графіки XX століття. К.: Грані-Т, 2007. 168 с.

2. Шевченко В. Композиція плаката: Навч. Посіб. Х.: Колорит, 2007. 133 с., іл..

3. https://back-in-ussr.com/2018/03/sovetskie-agitplakaty-budbditelen.html

4. https://oleksandr-klymenko.com/uk/uspishna-kraina/

5. https://ru.depositphotos.com/vectorimages/\%D0\%B7\%D0\%B2\%D0\%B5\%D0\%B7\%D0\%B4\%D0\%B0$\% \mathrm{D} 1 \% 81 \% \mathrm{D} 1 \% 81 \% \mathrm{D} 1 \% 81 \% \mathrm{D} 1 \% 80 . \mathrm{html}$

6. https://ru.wikipedia.org/wiki/\%D0\%9F\%D1\%80\%D0\%BE\%D0\%BF $\% \mathrm{D} 0 \% \mathrm{~B} 0 \% \mathrm{D} 0 \% \mathrm{~B} 3 \% \mathrm{D} 0 \% \mathrm{~B} 0 \% \mathrm{D} 0 \% \mathrm{BD} \% \mathrm{D} 0 \% \mathrm{~B} 4 \% \mathrm{D} 0 \% \mathrm{~B} 0 \_\% \mathrm{D} 0 \% \mathrm{~B} 2 \_\%$ $0 \% \mathrm{~A} 1 \% \mathrm{D} 0 \% \mathrm{~A} 1 \% \mathrm{D} 0 \% \mathrm{~A} 1 \% \mathrm{D} 0 \% \mathrm{~A} 0 \# /$ media/\%D0\%A4\%D0\%B0\%D0\%B9 \%D0\%BB:Soviet_Poster_4.jpg

7. https://sapiens.com.ua/ua/publication-single-page?id=140

DOI https://doi.org/10.30525/978-9934-26-004-9-77

\section{КОНФЛІКТНІСТЬ ЯК ПРИНЦИП МУЗИЧНОЇ ДРАМАТУРГІЇ У ФІЛЬМІ «ВОЛОДАР ПЕРСНІВ»}

\author{
Пожарська А.-О. Ю. \\ аспірант кафедри музикознавства та музичної освіти \\ Інституту мистеитв Київського університету імені Бориса Грінченка \\ м. Київ, Украӥна
}

Кіномузика посідає особливе місце у музичному мистецтві: вона водночас має характеристики автономного музичного твору та $\epsilon$ частиною синтетичного цілого - кінопродукту.

Дослідження кіномузики фільмів у жанрі фентезі є відносно молодим у музикознавстві. Наразі більшість науковців вивчає музику культового фільму «Володар Перснів», зокрема гармонічні і мелодичні особливості тем-лейтмотивів, а також їх роль у художній драматургії фільму [3]. У своїх роботах дослідники кіномузики «Володаря Перснів» розглядають музичну драматургію як частину художньої, тобто, як підпорядковану загальній драматургічній лінії фільму [6]. Проте Н. Дерда [2] висловила 